\title{
Induction of Differentiation of HL-60 Cells by the Anti-fungal Antibiotic, Radicicol
}

\author{
Yoko Shimada $^{\dagger * *}$, Tomoko OGaWa ${ }^{\dagger}$, Aiya Sato ${ }^{\dagger \dagger}$, Isao KaneKo ${ }^{\dagger \dagger \dagger}$ \\ and Yoshio TSUJITA ${ }^{\dagger}$ \\ ${ }^{\dagger}$ Pharmacology and Molecular Biology Research Laboratories, Sankyo Co., Ltd., \\ 1-2-58, Hiromachi, Shinagawa-ku, Tokyo 140, Japan \\ ${ }^{+\dagger}$ Biomedical Research Laboratories, Sankyo Co., Ltd., \\ Tokyo, Japan

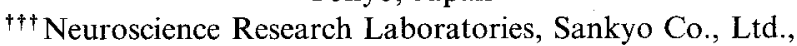 \\ Tokyo, Japan \\ (Received for publication November 18, 1994)
}

\begin{abstract}
The anti-fungal antibiotic, radicicol, produced in the culture broth of Neocosmospora tenuicristata, was found to induce differentiation of HL-60 cells into macrophages from the following evidence: (1) it caused morphological changes into macrophage-like cells, (2) induced NBT (Nitrobluetetrazolium) reduction activity, (3) induced phagocytosis, and (4) induced $\alpha$-naphthyl acetate esterase activity. The concentration of radicicol required to differentiate HL-60 cells is $50 \sim 100 \mathrm{ng} / \mathrm{ml}$, and the incubation time required for commitment of differentiation is 16 hours. Flow cytometry analysis indicated that radicicol blocks the cell cycle of HL-60 cells at the G1 and G2 sites. In addition, radicicol induced reversal of the transformed phenotype of ras-transformed NIH3T3 cells (DT cells) at $25 \mathrm{ng} / \mathrm{ml}$.
\end{abstract}

In vitro studies have shown that certain types of cultured tumor cells, such as leukemic, neuroblastoma, and melanoma cells, can be differentiated and their proliferation ceased by treatment with various differentiation inducers $^{1,2)}$. These include a kind of hormone ${ }^{3)}$, vitamine $^{4,5)}$, polas compound ${ }^{6}$, and modulators of oncogene functions ${ }^{7,8)}$. Among them, potent inducers such as $1,25(\mathrm{OH})_{2}$ vitamine $\mathrm{D}_{3}$ or dexamethasone were reported to exert antitumor activity in mice inoculated with myeloid leukemic cells ${ }^{9,10)}$.

These findings increased the possibility that induction of differentiation of tumor cells into normal cells is a new type of therapy for human cancer. It was reported by several investigators that low doses of cytosine arabinoside (Ara-C), which were sufficient to induce differentiation but not cytotoxic effects, are clinically available for myeloid leukemia patients ${ }^{11)}$. HuANG et al. ${ }^{12)}$ and CASTAIGNE et al. ${ }^{13)}$ showed that all-trans retinoic acid, a potent differentiation inducer for leukemic cells in vitro ${ }^{5}$, is also remarkably effective in attaining complete remission of acute promyelocytic leukemia patients.

With the aim of developing new cancer therapy drugs, we have screened differentiation-inducing compounds from microbial metabolites using human promyelocytic leukemia cells HL-60 ${ }^{14)}$. In this paper, we report that an anti-fungal antibiotic, radicicol (Fig. 1) ${ }^{15 \sim 17)}$, induces the differentiation of HL-60 into macrophage-like cells.

\section{Materials and Methods}

Purification of Radicicol

Radicicol ${ }^{15 \sim 17)}$ was produced in the culture broth of Neocosmospora tenuicristata cultivated in a 30-liter jar containing 15 liters of $5 \%$ glycerine, $5 \%$ potato homogenate, $5 \%$ malt extract, and $0.5 \%$ yeast extract, $\mathrm{pH} 6.0$, at $26^{\circ} \mathrm{C}$ for 6 days. Radicicol was extracted at neutral $\mathrm{pH}$, crystallized in ethyl acetate solution, and further purified by chromatography on an LH-20 column eluted by ethyl acetate - methylene chloride ( $1: 1)$, giving $450 \mathrm{mg}$ of radicicol with $98 \%$ purity.

Cell Lines and Culture

HL-60 cells were kindly provided by Dr. R. C. GaLlo (National Cancer Institute, U.S.A.). DT cells and B16BL6 cells were provided by Dr. M. NoDA and Dr. T. Tsuruo (Cancer Institute, Japan), respectively. ZR-75-1, L929 and Chinese hamster ovary (CHO) cells were purchased from Dainippon Pharmaceutical Co. Ltd. (Japan). HL-60 cells were cultured in RPMI-1640 medium (Nissui, Japan) containing $1 \%$ fetal calf serum (FCS, GIBCO) and 10\% GIT medium (Wako Pure

Fig. 1. Structure of radicicol.<smiles>CC1OC1/C=C\C=C/C(=O)Cc1c(Cl)c(O)cc(O)c1C(=O)OC(C)(C)O</smiles> 
Chemical Industries, Japan ). DT cells and L929 cells were cultured in Dulbecco's modified Eagle's medium (Nissui) containing 5\% FCS. ZR-75-1 cells were cultured in RPMI-1640 medium containing 10\% FCS. CHO cells and B16BL6 cells were cultured in Dulbecco's modified Eagle's medium containing $10 \%$ FCS. One hundred $\mathrm{U} / \mathrm{ml}$ penicillin $\mathrm{G}, 100 \mu \mathrm{g} / \mathrm{ml}$ streptomycin and $1.2 \mathrm{mg} / \mathrm{ml} \mathrm{NaHCO}$ were added to the media used in this study. All the incubations were carried out in a humidified $5 \% \mathrm{CO}_{2}$ and $95 \%$ air atmosphere at $37^{\circ} \mathrm{C}$.

Viable cell numbers of HL-60 and trypsinized ZR75-1 were assessed by trypan blue dye exclusion tests. Viabilities of the other cell lines were judged by 3(4,5-dimethyl-thiazoyl-2-yl)-2,5-diphenyl-tetrazolium bromide (MTT) assay ${ }^{18)}$. Briefly, cells cultured in 96 multi-well plates in the presence of test compounds, received $50 \mu \mathrm{l}$ of $1 \mathrm{mg} / \mathrm{ml}$ of MTT solution and were then incubated at $37^{\circ} \mathrm{C}$ for 4 hours. After the medium was discarded, the cells were dissolved in dimethylsulfoxide (DMSO), and the absorbance at $540 \mathrm{~nm}$ was measured.

Assays for Differentiation Markers of HL-60 Cells

Unless otherwise described, $2.5 \times 10^{5}$ of HL-60 cells were plated into 24 multi-well plates (Corning) containing $1 \mathrm{ml}$ of medium, and incubated for 72 hours in the presence of appropriate concentrations of test compounds. The cells harvested from each well were pelleted by centrifugation at $150 \times g$ for 3 minutes, and washed once with phosphate-buffered saline (PBS). For determining nitroblue tetrazolium (NBT) reduction activity ${ }^{19)}$, cells were resuspended in $200 \mu$ l of RPMI-1640 medium containing $1 \mathrm{mg} / \mathrm{ml}$ of NBT and $100 \mathrm{ng} / \mathrm{ml}$ of 12- $O$-tetradecanoylphorbol 13-acetate (TPA). After incubation at $37^{\circ} \mathrm{C}$ for 20 minutes, aliquots were taken to determine the percentage of cells with formazan deposits under light microscopy. The residual cells were pelleted and resolved in $750 \mu \mathrm{l}$ of DMSO, and their absorbance at $572 \mathrm{~nm}$ was determined.

Phagocytic activity was determined according to the method of Collins et al. ${ }^{20)}$. Briefly, HL-60 cells were washed once with PBS and resuspended in $1 \mathrm{ml}$ of culture medium containing $10 \%$ fresh human serum and $4 \times 10^{6}$ particles of heat-treated Candida albicans. After incubation at $37^{\circ} \mathrm{C}$ for 2 hours, the number of HL-60 cells which phagocyted more than 3 particles of Cabdida, was counted.

Nonspecific esterase activity was determined with a commercially available kit (Sigma).

Assays for Differentiation Markers of B16BL6 Cells and ZR-75-1 Cells

B16BL6 cells were plated into 96 multi-well plates (Corning) at a density of $4 \times 10^{3}$ cells/well with $100 \mu \mathrm{l}$ of medium. After 24 hours incubation, the medium was replaced with the test medium with or without inducers, and cells were incubated for a further 120 hours. At the end of the incubation, medium from each well was transferred into an empty plate. After the cells in the well were dissolved with $50 \mu 1$ of DMSO, the cell lysate and medium were pooled and their absorbance at $405 \mathrm{~nm}$ was measured for determination of melanin content.

ZR-75-1 cells were plated into 6 multi-well plates (Corning) at a density of $1 \times 10^{5}$ cells/well with $2 \mathrm{ml}$ of medium and cultured for 24 hours. The cells were then incubated for a further 120 hours in the presence or absence of inducers. The cells were scraped from the well by a rubber policeman and suspended in $5 \mathrm{ml}$ of PBS. The cells were pelleted by centrifugation at $150 \times g$ for 5 minutes, and washed once with PBS. Cellular lipid was extracted with $1 \mathrm{ml}$ of isopropyl alcohol, from which the triglyceride content was determined using a Triglyceride G-Test Wako kit (Wako Pure Chemical Industries, Japan).

\section{Flow Cytometry}

HL-60 cells fixed and permialized with $80 \%$ ethanol were resuspended in solution containing $50 \mu \mathrm{g} / \mathrm{ml}$ of propidium iodide, $0.1 \%$ Triton $\mathrm{X}-100$ and $3.8 \mathrm{~mm}$ sodium citrate, and incubated at $37^{\circ} \mathrm{C}$ for 30 minutes. The distribution pattern of the DNA content in the cell cycle was analyzed by flow cytometer (Coulter, EPICS 750), counting 10,000 cells for each assay.

\section{Results}

\section{Induction of Differentiation of HL-60 Cells}

The culture broth of Neocosmospora tenuicristata contained large amounts of a substance which reduced cell growth and increased the NBT reduction activity of HL-60. On purification, the differentiation-inducing compound was identified as radicicol (Fig. 1), an antifungal antibiotic isolated by DELMOTTIE ${ }^{5)}$.

Radicicol induced NBT reduction activity and reduced the growth of HL-60 cells dose dependently (Fig. 2). The concentration of radicicol required for $50 \%$ inhibition of cell growth ( $\mathrm{I}_{50}$ value) was $50 \mathrm{ng} / \mathrm{ml}$. By addition of $100 \mathrm{ng} / \mathrm{ml}$ of radicicol, which had no effect on the viability

Fig. 2. Suppression of cell growth and induction of NBT reduction activity by radicicol in HL-60 cells.

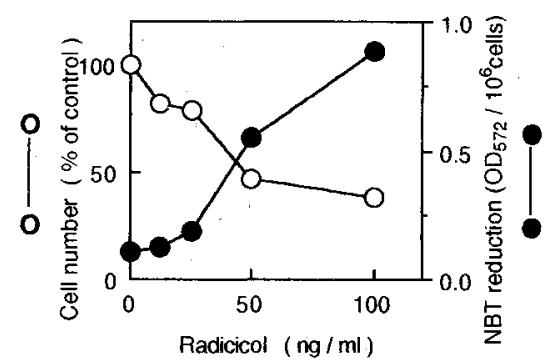

After incubation with the indicated concentrations of radicicol for 72 hours, NBT reduction activity (closed circle, see right vertical axis) and cell numbers (open circle, see left vertical axis) were determined. Each point represents the average of duplicate assays. 
of the HL-60 cells, $72 \%$ of the whole cell population became NBT reduction-positive, and $98 \%$ of the cells became phagocytic (Table 1).

In order to discover the incubation time required for commitment of differentiation by radicicol, HL-60 cells were treated with $100 \mathrm{ng} / \mathrm{ml}$ of radicicol for various periods, and their NBT reduction activities were determined at the end of 72-hour incubation. As indicated in Fig. 3, the cells incubated with radicicol for 16 hours and transferred to a radicicol-free medium showed an NBT reducing activity equal to that of the cells treated with radicicol-containing medium throughout 72 hours incubation. Treatment for less than 8 hours caused neither growth inhibition nor differentiation.

Table 1. Expression of differentiation markers in HL-60 cells by radicicol.

\begin{tabular}{lccc}
\hline \multirow{2}{*}{ Addition } & Conc. & \multicolumn{2}{c}{ Positive cell, \% } \\
\cline { 3 - 4 } & & 2 & 4 \\
\hline None & & 5 & 45 \\
Radicicol & $12.5 \mathrm{ng} / \mathrm{ml}$ & 19 & 56 \\
& $25 \mathrm{ng} / \mathrm{ml}$ & 28 & 87 \\
& $50 \mathrm{ng} / \mathrm{ml}$ & 72 & 98 \\
& $100 \mathrm{ng} / \mathrm{ml}$ & 56 & 95 \\
Retinoic acid & $300 \mathrm{ng} / \mathrm{ml}$ & 76 & 99 \\
DMSO & $1.3 \%$ & & 9 \\
\hline
\end{tabular}

HL-60 cells were incubated for 72 hours with the indicated compounds. Each value represents the average of duplicate assays.

Fig. 3. Induction of NBT reduction activity in HL-60 cells incubated with radicicol for various times.

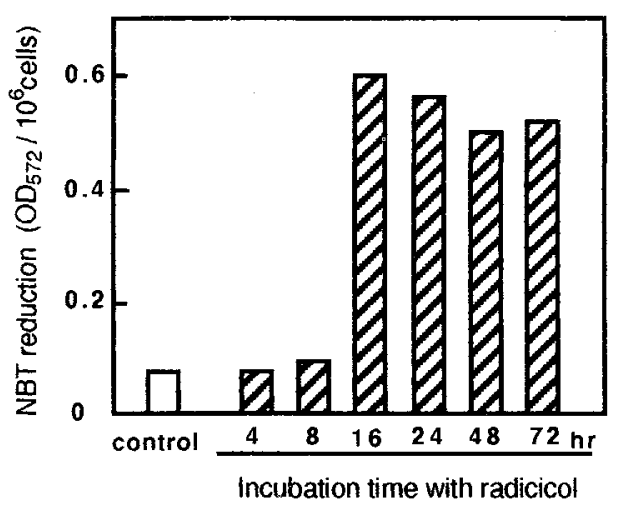

HL-60 cells which had been incubated with $100 \mathrm{ng} / \mathrm{ml}$ of radicicol (hatched bar) for the times indicated below each bar, were transferred into radicicol-free medium, and their NBT reducing activity was determined after 72 hours total incubation. Control cells (open bar) were incubated in the absence of radicicol throughout 72 hours. Each bar represents the average of duplicate assays.
Radicicol induced $\alpha$-naphthyl esterase activity in HL-60 cells in a dose-dependent manner (Fig. 4). By $50 \mathrm{ng} / \mathrm{ml}$ of radicicol, about $30 \%$ of cells were induced to express esterase activity. Although this percentage was much lower than that of the NBT reduction-positive or phagocytic cells (Table 1), it was comparable to the potential of $1 \mathrm{ng} / \mathrm{ml}$ of TPA which is known to differentiate HL-60 cells along the macrophage lineage ${ }^{21}$. In contrast, retinoic acid, a differentiation inducer towards granulocytes ${ }^{5)}$, did not induce esterase activity in HL-60 cells.

May-Gruenwald, Gimsa staining of HL-60 cells is shown in Fig. 5. Treatment with $100 \mathrm{ng} / \mathrm{ml}$ of radicicol for 72 hours caused a remarkable morphological change in the HL-60 cells, inducing typical features of macrophages. This result, together with the induction of $\alpha$ naphthyl acetate esterase, indicates that radicicol induces HL-60 to differentiate in a macrophage direction. Radicicol, however, hardly increased cell adherence to the substrate.

\section{Effect of Radicicol on Differentiation of B16BL6 and ZR-75-1 Cells}

The differentiation-inducing activity of radicicol was also evaluated in mouse melanoma B16BL6 cells and human mammary cancer ZR-75-1 cells (Fig. 6). When B16BL6 cells were incubated with radicicol for 120 hours, growth was reduced with an $I_{50}$ value of $230 \mathrm{ng} / \mathrm{ml}$. However, melanin production, which is a differentiation marker of this cell line $\mathrm{e}^{22,23}$, was not increased by addition of $500 \mathrm{ng} / \mathrm{ml}$ of radicicol. On the other hand, dibutyryl cyclic AMP, a known differentiation inducer for this cell line ${ }^{22,23}$ and also for HL-60 ${ }^{24)}$, increased melanin production by 4.5 fold over control cells.

In ZR-75-1 cells, although $870 \mathrm{ng} / \mathrm{ml}$ of radicicol

Fig. 4. Induction of $\alpha$-naphthyl acetate esterase activity by radicicol and other differentiation inducers in HL-60 cells.

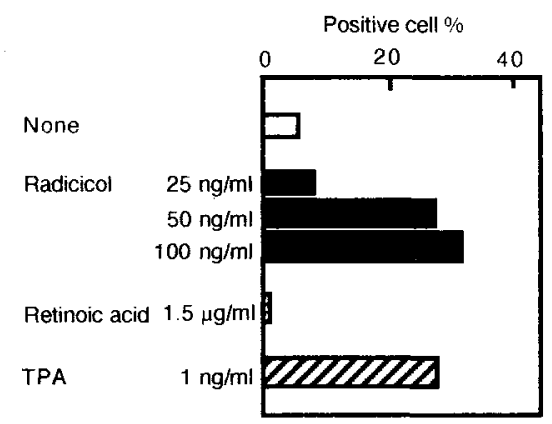

After HL-60 cells were incubated with the indicated compounds for 72 hours, the percentages of cells expressing esterase activity were determined. Each bar represents the average of duplicate assays. 
Fig. 5. Morphology of HL-60 cells stained with May-Grunwald-Giemsa.

(A) Untreated cells, (B) Cells treated with $100 \mathrm{ng} / \mathrm{ml}$ of radicicol for 72 hours. Original magnification, $\times 400$.

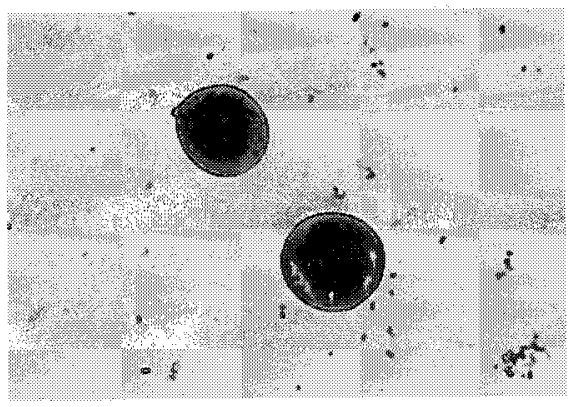

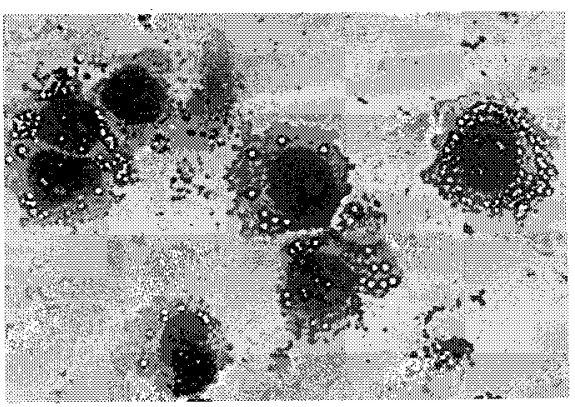

Fig. 6. Effect of radicicol on differentiation of B16BL6 and ZR-75-1 cells.
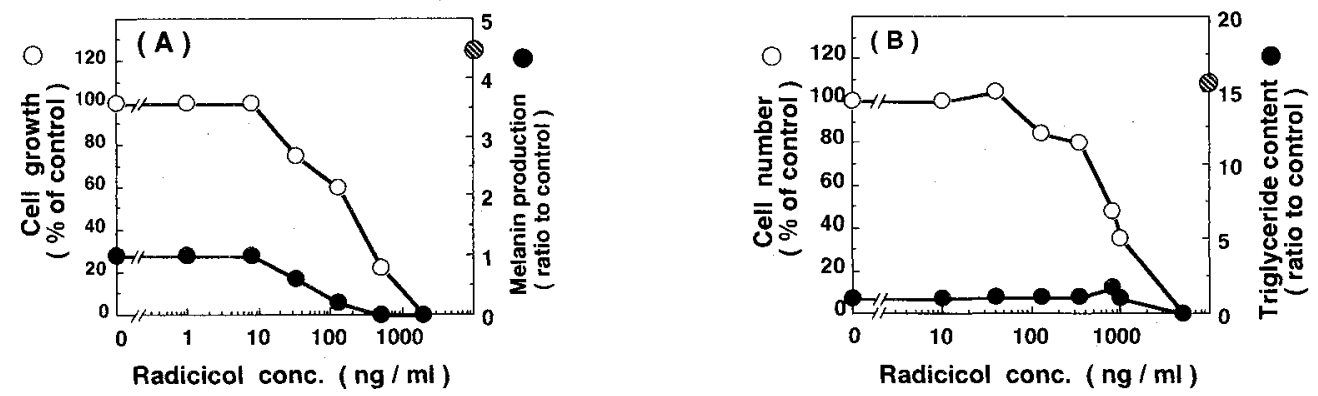

(A) B16BL6 cells were treated with the indicated concentrations of radicicol for 120 hours and were assessed for cell growth (open circle, see left vertical axis) and melanin production (closed circle, see right vertical axis). Hatched circle expresses the melanin production in cells treated with $0.125 \mathrm{~mm}$ dibutyryl-cyclic AMP. Each point represents triple assays.

(B) ZR-75-1 cells were treated with the indicated concentrations of radidicol for 120 hours and were assessed for cell growth (open circle, see left vertical axis) and triglyceride content (closed circle, see right vertical axis). Hatched circle expresses the triglyceride content in cells treated with $1 \mathrm{~mm}$ sodium butyrate. Each point represents the average of duplicate assays.

reduced cell growth to $50 \%$ of control after 96 hours incubation, it did not induce accumulation of triglyceride in the cells even at a concentation of $1,000 \mathrm{ng} / \mathrm{ml}$. Treating ZR-75-1 cells with sodium butyrate, a differentiation inducer ${ }^{25}$, caused a 16 -fold accumulation of triglyceride in the cells compared with the control.

Thus, radicicol has no capacity to induce differentiation of B16BL6 or ZR-75-1, suggesting that the differentiation of HL- 60 cells by radicicol is not mediated through the accumulation of cyclic AMP.

\section{Kinetics of Growth Inhibition by Radicicol}

The susceptibility of HL-60 to radicicol was compared under different cell density conditions (Fig. 7). The cells plated at a low cell density $\left(2.5 \times 10^{5}\right.$ cells $\left./ \mathrm{ml}\right)$, which grew rapidly during 48 hours incubation, were sensitive to growth inhibition of radicicol, giving an $I_{50}$ value of $50 \mathrm{ng} / \mathrm{ml}$. On the other hand, for the cells plated at a high cell density $\left(1.5 \times 10^{6} \mathrm{cells} / \mathrm{ml}\right)$, of which proliferation did not proceed further during 48 hours, it required
Fig. 7. Effect of radicicol on growth of HL-60 cells plated at low or high cell density.

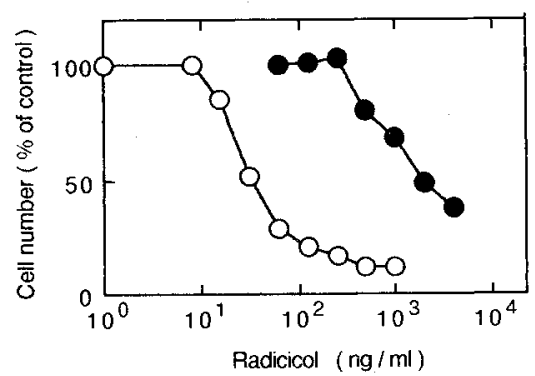

HL- 60 cells were plated at a density of $2.5 \times 10^{5}$ cells $/$ well (open circle) or $1.5 \times 10^{6}$ cells/well (closed circle) into 24 well multi-well plates, and the indicated concentrations of radicicol were added. After incubation for 48 hours, the numbers of cells were counted. Each point represents the average of duplicate assays.

more than $2,000 \mathrm{ng} / \mathrm{ml}$ of radicicol to decrease the numbers of viable cells to $50 \%$ of the control. The latter action of radicicol may be attributed to cytotoxity. On measuring the amount of radicicol in the medium by 
HPLC analysis after incubation with the cells, the value obtained in the high cell-density condition was the same as that in the low (data not shown).

Flow cytometry analysis was carried out to find out the inhibition site of radicicol in the cell cycle of growing cells. As shown in the DNA histogram in Fig. 8, accumulation of cells at the $2 \mathrm{C}$ and $4 \mathrm{C}$ peaks was observed in HL-60 treated with $100 \mathrm{ng} / \mathrm{ml}$ of radicicol for 48 hours. The cells distributing between $2 \mathrm{C}$ and 4C peaks, which corresponded to the S-phase, were markedly decreased by radicicol. This DNA histogram pattern, together with the lack of appearance of M-phase cells under light microscopy (data not shown), suggests that radicicol inhibits progression from $\mathrm{G} 1$ into the S-phase, and also blocks cell cycle at the G2 site.

Radicicol also exerted its growth-inhibition effects on CHO cells and mouse L-929 cells (Fig. 9). In both cell lines, rapidly growing cells, which were plated at a low

Fig. 8. Effect of radicicol on DNA contents of HL-60 cells.
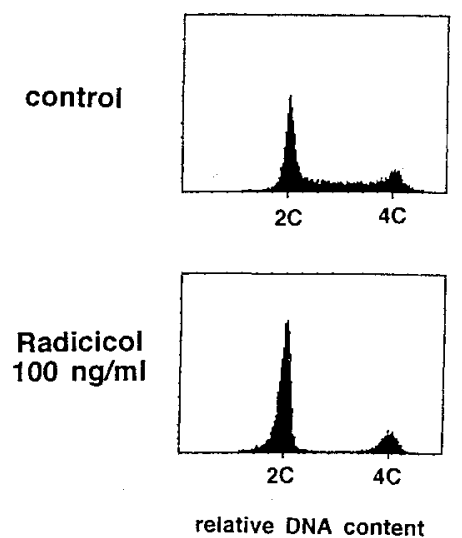

HL- 60 cells $\left(2.5 \times 10^{5} / \mathrm{ml}\right)$ were incubated in the presence or absence of $100 \mathrm{ng} / \mathrm{ml}$ of radicicol for 48 hours, after which the distribution of DNA contents was analyzed by flow cytometry.

Table 2. Comparison of growth inhibitory concentrations of radicicicol in various cell lines.

\begin{tabular}{|c|c|c|}
\hline Cell line & $I_{50}$ & value $^{*}(\mathrm{ng} / \mathrm{ml})$ \\
\hline $\mathrm{HL}-60^{\mathrm{a}}$ & & 50 \\
\hline B $16 \mathrm{BL}^{\mathrm{b}}$ & & 230 \\
\hline ZR-75-1 ${ }^{\mathrm{b}}$ & & 870 \\
\hline L929 a & & 200 \\
\hline $\mathrm{CHO}^{\mathrm{a}}$ & & 500 \\
\hline
\end{tabular}

* Concentration of radicicol required for $50 \%$ inhibition of cell growth.

a Incubation time with radicicol was 72 hours.

b Incubation time with radicicol was 120 hours. cell density, were over 10 times more highly susceptible to radicicol compared with cells in the nearly confluent state. Comparisons of the $I_{50}$ values of radicicol in various cell lines in the rapidly-growing state, among which HL-60 was the most sensitive, are shown in Table 2.

\section{Effect of Radicicol on the Morphology of Ras-transformed Cells}

In order to examine the effect of radicicol on oncogene function, DT cells, NIH3T3 cells transformed by the introduction of 2 copies of v-ras ${ }^{26)}$, were treated with radicicol. The concentration of radicicol required for $50 \%$ inhibition of cell growth was $65 \mathrm{ng} / \mathrm{ml}$ after 48 hours incubation. As shown in Fig. 10, DT cells incubated in the presence of $25 \mathrm{ng} / \mathrm{ml}$ of radicicol for 20 hours became flat like normal NIH3T3 cells, whereas control DT cells exhibited a round shape.

\section{Discussion}

It was indicated in this study that an anti-fungal antibiotic, radicicol ${ }^{15 \sim 17)}$, blocks the cell cycle of HL-60 cells at the $\mathrm{G} 1$ and $\mathrm{G} 2$ sites, and induces irreversible differentiation along the macrophage lineage. These phenomena were observed at $50 \sim 100 \mathrm{ng} / \mathrm{ml}$, which is a much lower concentration range than that giving antifungal activity, ranging from $3 \sim 300 \mu \mathrm{g} / \mathrm{ml}^{15,17)}$. Radici-

Fig. 9. Effect of radicicol on cell growth of $\mathrm{CHO}$ cells and L929 cells.

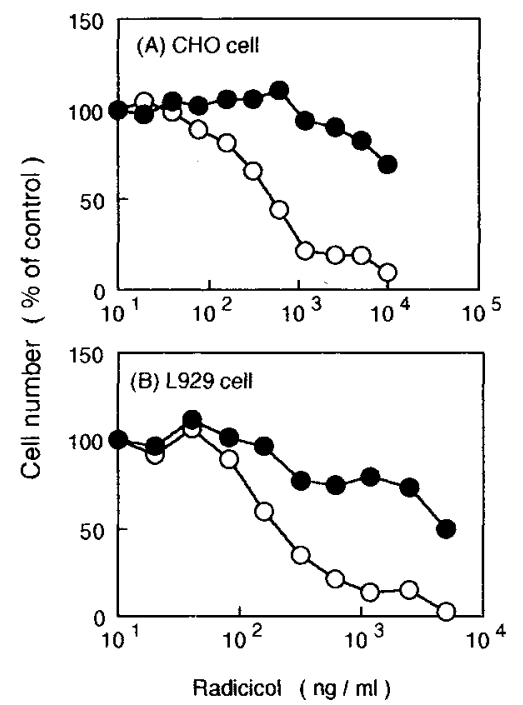

CHO cells (A) were plated into 96 well multi-well plates at a density of $5 \times 10^{3}$ cells $/$ well (open circle) or $5 \times 10^{4}$ cells/ well (closed circle).

L929 cells (B) were plated into 96 well multi-well plates at a density of $2 \times 10^{3}$ cells/well (open circle) or $2 \times 10^{4}$ cells/ well (closed circle).

After incubation with the indicated concentrations of radicicol for 72 hours, viable cell numbers were determined. Each point represents the average of duplicate assays. 
Fig. 10. Morphological changes in DT-cells caused by radicicol.

A

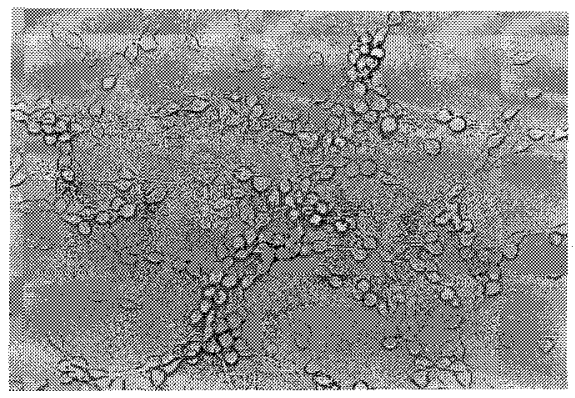

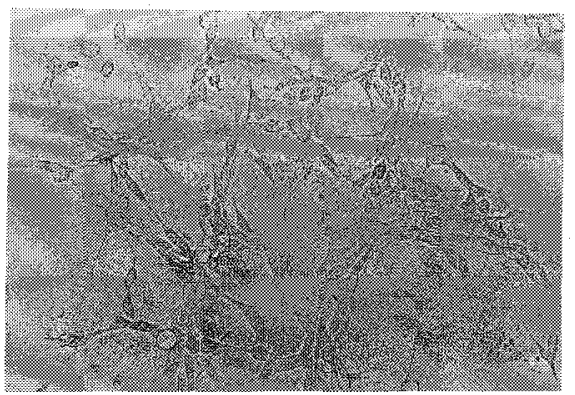

DT-cells were plated into 24 well multi-well plates at a density of $2 \times 10^{4}$ cells/well and cultured for 24 hours. The cells were then incubated in the (A) absence or (B) presence of $25 \mathrm{ng} / \mathrm{ml}$ of radicicol for 20 hours, after which the morphology of the cells was examined by light microscopy. Original magnification, $\times 400$.

col also had cytotoxic activity at high doses equivalent to anti-fungal concentrations. Comparing these concentrations, the differentiation-inducing activity seems to be the most specific action among the various biological activities of radicicol.

Radicicol had no differentiation-inducing effect on ZR-75-1 or B16BL6 cells, in spite of showing growth inhibition, suggesting that no protein kinase A-mediated reaction is involved in the differentiation of HL-60 cells by radicicol.

KwON et al. have already reported biological activities of radicicol other than anti-fungal action ${ }^{27,28)}$; (1) induction of reversal of the transformed phenotype of both v-src-transformed and c-erbB-2-transformed 3Y1 cells, (2) G1G2 arrest of rat 3Y1 cells, (3) inhibition of tyrosine kinases of both src and receptor types, (4) induction of differentiation of Friend leukemia cells. These phenomena were observed at around $100 \mathrm{ng} / \mathrm{ml}$ of radicicol. Differentiation of Friend leukemia cells is already known to be associated with the inhibition of tyrosine kinase ${ }^{29}$. The fact that radicicol also inhibits growth of normal cells such as CHO cells and L929 cells (Fig. 9) may be attributed to the inhibition of tyrosine kinase. Besides, reversal of the transformed phenotype of DT cells by radicicol in our study might result from inhibition of tyrosine kinase, as ras is located downstream of regulation by receptor type tyrosine kinase $^{30)}$. Although it should be notable that ras is activated in HL-60 cells together with myc alteration ${ }^{31)}$, the mechanism of HL-60 differentiation by radicicol, and its relation to tyrosine kinase, ras fuction and G1G2 arrest, must be solved by further work.

The $\mathrm{LD}_{50}$ value of radicicol in mouse acute-toxicity tests was between 300 and $1,000 \mathrm{mg} / \mathrm{kg}$ by oral administration (our preliminary experiment). In addition to the low toxicity in vivo, the fact that radicicol also exhibited cytostatic activity on P388 cells, L1210 cells and M5076 cells at as low as $10 \mathrm{ng} / \mathrm{ml}$ in vitro (data not shown), prompted us to evaluate the potency of this compound in vivo. Anticancer tests of radicicol in tumorbearing mice are now in progress.

\section{Acknowledgments}

The authors wish to thank Dr. F. Isono for his suggestion in experiment of DT-cells. Thanks are also due to Dr. T. KoBAYASH for his valuable advice during the preparation of this manuscript.

\section{References}

1) Hozumi, M.: A new approach to chemotherapy of myeloid leukemia cells by inducer of normal differentiation. In Cancer Biology Reviews. Ed., J. J. Marchalonis \& M. G. Hanna. Vol. 3, pp. 153 211, Marcel Dekker, New York, 1982

2) Revoltella, R. P.; G. M. Pontieri, C. Basilico, G. Rovera, R. C. Gallo \& J. H. Subak-Sharpe (Ed.): Expression of differentiated functions in cancer cells. Raven Press, New York, 1982

3) Honma, Y.; T. Kasukabe, J. OKabe \& M. Hozumi: Glucocorticoid-induced differentiation of cultured mouse myeloid leukemia cells. Gann 68: $241 \sim 246,1977$

4) Abe, E.; C. Miyaura, H. Sakagami, M. Takeda, K. Konno, T. Yamazaki, S. Yoshiki \& T. Suda: Differentiation of mouse myeloid leukemia cells induced by 1,25-dihydroxyvitamin $D_{3}$. Proc. Natl. Acad. Sci. U.S.A. 78: $4990 \sim 4994,1981$

5) Breitman, T. R.; S. E. Selonick \& S. J. Collins: Induction of differentiation of the human promyelocytic leukemia cell line (HL-60) by retinoic acid. Proc. Natl. Acad. Sci. U.S.A. 77: 2936 2940, 1980

6) Spremuli, E. N. \& D. L. Dexter: Polor solvents: a novel class of antineoplastic agents. J. Clin. Oncol. 2: 227 241, 1984

7) Honma, Y.; J. OKabe-Okada, M. Hozumi, Y. Uehara \& S. Mizumo: Induction of erythroid differentiation of K562 human leukernic cells by herbimycin A, an inhibitor of tyrosine kinase activity. Cancer Res. 49: $331 \sim 334$, 1989

8) Uehara, Y.; M. Hori, T. Takeuchi \& H. Umezawa: Phenotypic change from transformed to normal induced by benzoquinonoid amsamycins accompanies inactivation of p60src in rat kidney cells infected with Rous sarcoma virus. Mol. Cell. Biol. 6: 2198 2206, 1986

9) Honma, Y.; T. Kasukabe, J. OKabe \& M. Hozumi: Prolongation of survival time of mice inoculated with 
myeloid leukemia cells by inducers of normal differentiation. Cancer Res. 39: 3167 3171, 1976

10) Honma, Y.; M. Hozumi, E. Abe, K. Konno, M. Fukushima, S. Hata, Y. Nishi, H. F. Deluca \& T. Suda: 1,25-dihydroxy vitamine $\mathrm{D}_{3}$ and 1-hydroxy vitamine $\mathrm{D}_{3}$ prolong survival time of mice inoculated with myeloid leukemia cells. Proc. Natl. Acad. Sci. U.S.A. 80: $201 \sim 204$, 1983

11) Houssert, M.; M. T. Daniel \& L. Degos: Small doses of ARA-C in the treatment of acute leukemia: differentiation of myeloid leukemia cells? Brit. J. Haematol. 51: 125 129, 1982

12) Huang, M.; Y. Ye, S. Chen, J. Chai, J. Lu, L. Gu \& Z. WANG: Use of all-trans retinoic acid in the treatment of acute promyelocytic leukemia. Blood 72: 567 572, 1988

13) Castaigne, S.; C. Chomienne, M. T. Daniel, P. Ballerini, R. Berger, P. Fenaux \& L. Degos: All-trans retinoic acid as a differentiation therapy for acute promyelocytic leukemia. I. Clinical results. Blood 76: $1704 \sim 1709,1990$

14) Collins, S. J.; R. C. Gallo \& R. E. Gallagher: Continuous growth and differentiation of human myeloid leukemic cells in suspension culture. Nature (London) 270: $347 \sim 349,1977$

15) Delmotte, P.\& J. Delmotte-Plaquee: A new antifungal substance of fungal origin. Nature (London) 171: 344, 1953

16) Mirrington, R. N.; E. Richie, C. W. Shoppee, W. C. TAYLOR \& S. STERnhell: The constitution of radicicol. Tetrahedron Lett. 7: 365 370, 1964

17) McCapra, F.; A. X. Scott, P. Delmotte, J. DelmottePlaqueE \& N. S. BHACCA: The constitution of monorden, an antibiotic with tranquilizing action. Tetrahedron Lett. 15: $869 \sim 875,1964$

18) Green, L. M.; J. L. Reade \& C. F. Ware: Rapid coloremetric assay: application to the quantitation of cytotoxic and growth inhibitory lymphokines. J. Immunol. Methods 70: $257 \sim 268,1984$

19) Collins, S. J.; A. Bodner, R. Ting \& R. C. Gallo: Induction of morphological and functional differentiation of human promyelocytic leukemia cells (HL-60) by compound which induce differentiation of murine leukemia cells. Int. J. Cancer 25: $213 \sim 218,1980$

20) Collins, S. J.; F. W. Ruscetti, R. E. Gallagher \& R. C. Gallo: Terminal differentiation of human promyelocytic leukemia cells induced by dimethyl sulfoxide and other polar compounds. Proc. Natl. Acad. Sci. U.S.A. 75: $2458 \sim 2462,1978$
21) Rovera, G.; D. Santoli \& C. Damsky: Human promyelocytic leukemia cells in culture differentiate into macrophage-like cells when treated with a phorbol diester. Proc. Natl. Acad. Sci. U.S.A. 76: 2779 2783, 1979

22) Giuffre, L.; M. Schreyer, J. P. Mach \& S. Carrel: Cyclic AMP induces differentiation in vitro of human melanoma cells. Cancer 61: 1132 1141, 1988

23) Kreider, J. W.; M. Rosenthal \& N. Lengle: Cyclic adenosine 3',5'-monophosphate in the control of melanoma cell replication and differentiation. J. Natl. Cancer Inst. 50: $555 \sim 558,1973$

24) Tortora, G.; T. Clair \& Y. S. Cho-Chung: An antisense oligonucleotide targeted against the type II regulatory subunit mRNA of protein inhibits cAMPinduced differentiation in HL-60 leukemia cells without affecting phorbol ester effects. Proc. Natl. Acad. Sci. U.S.A. $87:$ 705 708, 1990

25) Graham, K. A. \& R. N. Buck: Sodium butyrate induces differentiation of breast cancer cell lines expressing the estrogen receptor. J. Cell Physiol. 136: 63 71, 1988

26) Noda, M.; Z. Selinger, E. M. SCOlNick \& R. H. Bassin: Flat revertants isolated from Kirsten sarcoma virustransformed cells are resistant to the action of specific oncogenes. Proc. Natl. Acad. Sci. U.S.A. 80: 5602 5606, 1983

27) Kwon, H. J.; M. Yoshida, K. Abe, S. Horinouch \& T. BEPPU: Radicicol, an agent inducing the reversal of transformed phenotypes of src-transformed fibroblasts. Biosci. Biotech. Biochem. 56: 538 539, 1992

28) Kwon, H. J.; M. Yoshida, Y. Fukui, S. Horinouchi \& T. BEPPU: Potent and specific inhibition of $\mathrm{p} 60^{\mathrm{v}-\mathrm{src}}$ protein kinase both in vivo and in vitro by radicicol. Cancer Res. 52: $6926 \sim 6930,1992$

29) Kondo, K.; T. Watanabe, H. Sasaki, Y. Uehara \& M. OISHI: Induction of in vitro differentiation of mouse embryonal carcinoma (F9) and erythroleukemia (MEL) cells by herbimycin A, an ihibitor of protein phosphorylation. J. Cell Bio. 109: 285 293, 1989

30) Cantley, L. C.; K. R. Augen, C. Cartenter, B. Duckworth, A. Graziani, R. Kapeller \& S. Soltoff: Oncogenes and signal transduction. Cell 64: $281 \sim 302$, 1991

31) Murray, M. J.; J. M. Cunningham, L. F. Parada, F. Dautry, P. Lebowitz \& R. A. Weinberg: The HL-60 transforming sequence: a ras oncogene coexisting with altered myc genes in hematopoietic tumors. Cell 33: $749 \sim 757,1983$ 